Año XLVIII. urtea

$122-2016$

Uztaila - abendua

Julio - diciembre

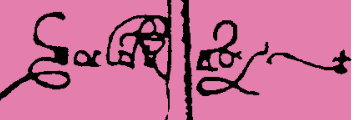

Gat

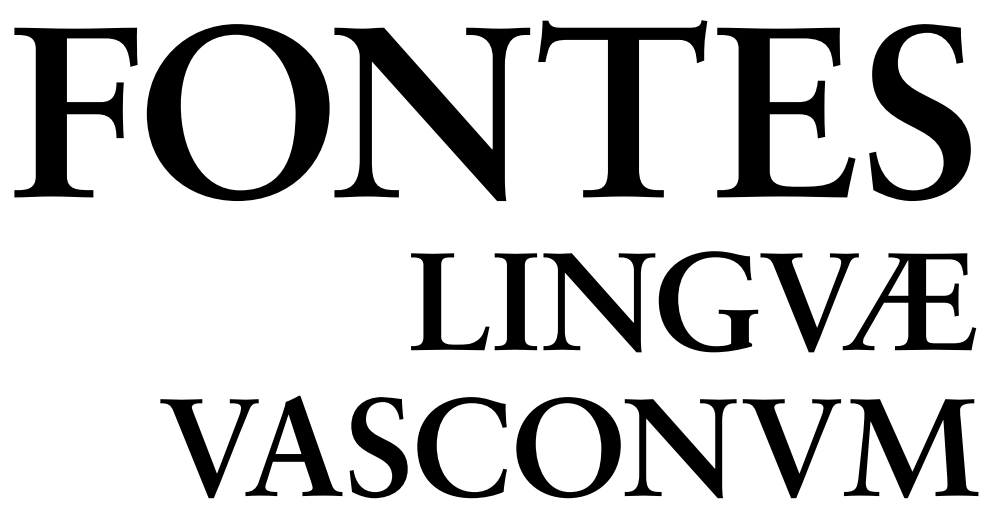

STVDIA ET DOCVMENTA
SEPARATA

\section{Julian Gaiarreren euskal gutuna: edizioa eta azterketa}

Koldo ULIBARRI

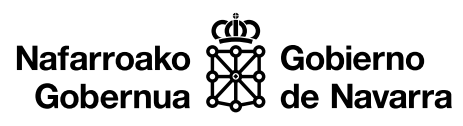

0000 


\section{Sumario / Aurkibidea}

\section{Fontes Linguae Vasconum. Studia et Documenta}

Año XLVIII. urtea - N. o 122. zk. - 2016

Uztaila - abendua / Julio - diciembre

Erroibarko aldaeraren inguruan

(3 - Hego Erroibarko azpialdaera. Bigarren erdia)

Koldo Artola

Etxarrierako hitano-alokutiboa

Jose Luis Erdozia

An introduction to Basque aspiration: the contribution of onomastics

Patxi Salaberri Zaratiegi, Iker Salaberri Izko

Urretabizkaiaren eta Sarrionandiaren itzulpen-habitusak

Miren Ibarluzea

Julian Gaiarreren euskal gutuna: edizioa eta azterketa

Koldo Ulibarri

Zozo zuriaren xerka: euskararen optatiboaren historia

Manuel Padilla-Moyano

Euskarazko erlatiboen diakroniaz: testu zaharren azterketa

Dorota Krajewska 


\section{Julian Gaiarreren euskal gutuna: edizioa eta azterketa}

Koldo Ulibarri $^{1}$

UPV/EHU

Sebastian Julian Gaiarre (Erronkari, 1844-Madril, 1890), zerbaitengatik ezaguna bada, XIX. mendearen bukaerako opera munduan izan ziren tenorretatik onenetarikoa izateagatik da; eta horrela ageri da musikaren historiari buruzko eta Nafarroako gizon garrantzitsuenei buruzko lanetan. Bibliografia horietan, behin baino gehiagotan irakur daiteke haren gutunen artean euskaraz idatziriko bat bederen badela, 1884an izeba Juanari bidalia. Dakigularik, baina, gutun hori gutxitan aipatu izan da erronkarierazko lekukotasunen artean, bere tamaina txikiagatik edo ( $88 \mathrm{hitz}$ baino ez ditu), eta ondorioz haren datuak gutxitan erabili dira erronkarieraren deskribapen eta azterketetan. Ikertzaileren batek gutuntxoa aipatzen duenean, gainera, anekdota legez aipatzen duela iruditu zaigu; hots, badirudi Erronkariko tenorrak euskara bazekiela bermatzeko erabiltzen dela, baina ez euskalki horren lekukotasun bezala duen balio linguistiko eta historikoagatik.

1 Lan hau egiteko, ezinbestekoak izan dira hainbat lagun eta adiskide: lehenik Gorka Lekarozek dokumentuaren erreprodukzioa eskuzabal eskaini eta lanari ohar interesgarriak egin ditu; bigarrenik, Blanca Urgell eta Iñaki Caminok lanaren hainbat bertsio irakurri dituzte eta guztiei ohar interesgarri asko egin dizkiete. Azkeneko momentuan Mikel Martinez Aretaren zenbait ohar ere jaso ahal izan ditut artikuluan. Zorretan nago baita Ander Egurtzegirekin ere, abstracta itzultzeko emandako laguntzagatik. Guztiek lan hobea egiten lagundu didate eta bihoazkio hemendik neure esker onak guztiei; nola ez, honek ez du esan nahi testuan agertzen diren hipotesi eta akatsak eurei leporatu behar zaizkienik, artikuluaren idazleari bakarrik baitagozkio. Amaitzeko, esan behar da lan hau «Monumenta Linguae Vasconum (IV): Textos Arcaicos Vascos y Euskera Antiguo» (MINECO, FFI2012-37696), «Historia de la lengua vasca y lingüística histórico-comparada» (Gobierno Vasco, GIC. IT698-13) eta «Lingüística teórica y diacrónica: Gramática Universal, lenguas indoeuropeas y lengua vasca» (UPV/EHU, UFI11/14) proiektuen barruan kokatzen dela. 
Lan honetan erremedio eman nahiko genioke egoera horri, eta gure ustez merezi duen arreta eskaini gutunari, bere edizioa eta azterketa eginez. Horretarako, lehenik eta behin testuinguruan kokatu behar dugu: hasteko, erronkarieraren inguruan eman diren zenbait iritzi gainetik azalduko ditugu, eta horrekin batera euskara hori ezagutzeko diren baliabide nagusiak (i. e., testu nagusiak) laburki aurkeztuko $(\S 1)$. Ondoren, Julian Gaiarreren bizitzaren zertzelada batzuk eskainiko ditugu ( $(2)$, haren gutunaren testuinguru historikoa erakutsi nahirik.

Hirugarren ataletik aurrera gutunaren edizioari ekingo diogu: lehenbizi, gutunaren testu tradizioa erakusteko, orain artean egin diren edizio garrantzitsuenak, edo entzutetsuenak behintzat, agertu eta deskribatuko dira, bai eta ere azalduko edizioa atontzeko erabili ditugun irizpideak ( $\$ 3)$. Ondoren edizioa bera etorriko da (§ 4), ohar paleografiko, aparatu kritiko eta ohar linguistikoz lagunduta. Amaitzeko (§ 5), hizkeraren azterketak ekarri dizkigun zenbait ondorio eta sortu zaizkigun zenbait galdera aurkeztuko dizkiogu irakurleari.

Hau Erronkaribarreko lekukotasun ahantzi bati buruzko artikulua izanik, eranskin gisa Jose Maria Arakistain fraide karmeldarrak 1746an Larramendiri bidalitako hitz zerrendetako bat editatuko dugu, Erronkarin egindako egonaldian bildurikoa, hain zuzen ( $c f r$. Mitxelena, 1970: 172). Dakargun edizio hau behin-behinekotzat baino ezin da hartu: edizio kritikoa beste batean (edo beste norbaitek) egin bitartean baliagarri izan litekeelakoan.

\section{ERRONKARIBARREKO EUSKARAZ}

Erronkaribarra Nafarroako lurralde ekialdekoena da, iparraldean Zuberoa eta ekialdean Aragoiko Anso Ibarra mugakide dituela. Zazpi herri ditugu Eska ibaiak zeharkatzen duen ibar honetan: Bidankoze, Burgi, Erronkari, Garde, Izaba, Urzainki eta Uztarroze. Aspalditik da ezaguna Erronkaribarreko euskararen berezitasuna: dakigularik, hizkeraren lehenengo aipamen zehatza XviII. mendean egin zuen Etxeberri Sarakoak. Euskalkien arteko ulergarritasunaz ari dela, lapurtarrak esaten digu «Ochagabiarra edo erroncalesa baztandarrarequin eta lau-urtarrarequin» batuko balira «ikhusico duçu elkhar ecin adi deçaquete [...]»(HH. EE., 1987: 473; cfr. Bilbao, 2006: 347), ordurako Erronkariko euskarak gainontzeko hizkerekin zuen berezitasuna iradokirik. Garai bertsuan erronkarieraren lehenengo datu bilketa egin zuen J. A. Arakistainek (1746), eta M. Larramendiri bidali zizkion bilketaren emaitzak hiztegiaren eranskintzat erabil zitzan, gutunean zehaztapen hau eginik: «Este verano estuve cuatro ó cinco dias en la villa de Roncal; y advertí algunos términos vascongados bien extraordinarios; y los apunté para remitirselos á Vuestra Revendisima, si acaso le pueden servir para algo» (Fita, 1880: 42).

Agerian denez, fraide karmeldarrak erronkarieraren berezitasun lexikoaz jabetu eta bilduman hitz zerrenda bereizi batean ematen du herri horretako materiala; ostera, ondoko zerrendetan ez du honetan bezain zehatz jokatzen: "Otros [términos] de Navarra y Guipúzcoa» (ik. Fita, 1880: 43). Hala bada, Arakistain Bonaparteren 
aurrekari dugu Erronkariko euskalkiaren interes zientifikoari antzematen (Mitxelena, 1970: 172), nahiz haren lana luzaroan ezezaguna izan. Dena dela, Bonaparte printzeari zor zaio Erronkaribarreko hizkera Pirinioen magaletatik zientziaren ikusmirara atera izana; beherago ikusiko denez, haren corpusaren atalik garrantzitsuena haren babesean osatu zen.

Euskalkien lehenengo sailkapenean zubereraren barruan kokatu zuen Bonapartek (Yrizar, 1949: 105 e. hh.), baina, bere «euskalki kuttun» bihurturik, ordutik aurrera Euskal Herrira egindako bidaia guztietan erronkarieraz arduratu zen bereziki (bidaien nolakoaz jabetzeko, ik. Yrizar, 1949). Lehenengo sailkapen hura aldatuko ez zuen, baina Erronkaribarreko euskararen deskribatze xeheago bat egin zuen, Bidankozeko, Urzainkiko eta Uztarrozeko aldaerak bereiziz. Era berean, azterketa aurrera joan ahala, behin eta berriz bere usteak birplanteatu (HH. EE., 1987: 473), eta erronkariera euskalki beregaina izan zitekeela iradokitzera heldu zen azken garaietan (Yrizar, 1949: 123).

Ondoren Azkuek hartuko zuen Bonaparteren lekukoa, eta Printzearen azken proposamen hori aurrerago eramanez euskalki beregaintzat hartuko: 1905ean argitaratu zuen hiztegian $\mathrm{R}$ laburdurarekin adieraziko zituen erronkarierazko hitzak, zubereratik (S) ondo bereizirik (Mitxelena, 1964: 25): zergatia zehaztua genuke erronkarierari eskaini zion lan monografikoan, haren ustez ez baitzegoen alde gutxiago euskaran Erronkaribarretik Zuberoara Lapurditik Gipuzkoara baino (Azkue, 1931). Hemen genuke bigarren mugarria, ordutik eta erronkarieraren heriotzara arte euskalki beregaintzat hartu izan baita, agian, Mitxelenaren hitzetan (1964: 25), «ya que resulta útil por su comodidad». Mitxelenak ere begiko zuen erronkariera: landa-lanean aritu ohi ez bazen ere, inkestarik egin zuen hizkera bakarra izan bide zen, eta bildurikoa lan monografikoetan argitaratu zuen (Mitxelena, 1953, 1954); besteak beste, Fonética Histórica Vasca-ren $[F H V]$ hitzaurrean aipamen berezia du, bazterreko euskalkiak baitira «los más importantes en la comparación» $(F H V, 16)$. Aski dira bildutako ale apurrok Erronkariko euskararen berezitasuna azpimarratzeko, hainbeste ikertzaileren eta hain garrantzizkoren arreta erakartzeko modukoa.

Erronkariera deskribatu eta bere ibilbide historikoa marrazteko orduan, baina, arazoak ditugu, lekukotasunetan, are gutxiago testu zaharretan, ez baita nahi genukeen bezain joria. Euskara Arkaikoan (1600. urtera arteko euskaran; ik. Lakarra 1997: 416) Burgiko sorginen aurkako auzi batean transkribaturiko esaldi labur bat(zuk) baino ez dugu (cfr. Camino 2011: 97), eta Euskara Zahar eta Klasikoan (1600-1745) argitaratzear diren Migel Ros Erronkari herriko notarioak Zuberoako Etxart jaunari bidaliriko gutunak (Bilbao et al., 2016), orduko Erronkariko euskararen nola edo halako lekuko direnak, bai eta goian aipaturiko Arakistain karmeldarrak (1746) egindako hitz bilduma bera ere (ik. artikulu honen eranskina).

Bonaparte printzeak egindako euskalkien datu bildumari esker, xIx. mendean Erronkariko euskararen corpusa handitu zen. Honen aurrekoa bide da Doctrina uscaraz (XIX. mende hasierakoa?; ik. Gómez, 1991), Erronkarikoa edo, egiantzekoago apika, Urzainkikoa. Gainerakoak Bonaparteren aginduz egindakoak dira: batetik, Hualde 
Mayok itzuliriko dotrina eta San Mateoren Ebanjelioa ditugu eta, bestetik, Bonaparteren bilduman gordetzen diren Doctrina Christiaia (ustez Erronkarikoa) eta ibarreko beste dotrina zati gehiago ere (Pagola et al., 1997). Jada xx. mendean, Mendigatxak Azkueri bidalitako gutunak ditugu (Estornés Lasa, 1984) eta 50eko hamarkadan hasi ziren azken lekukoen ahozko bilketa lanak, argi baitzegoen euskalkia hilzorian ${ }^{2}$ zela. 70 eta 80 ko hamarkadetan zehar, Koldo Artolak, Koldo Izagirrek eta José eta Bernardo Estornés Lasa anaiek Mitxelenak eta bestek hasitako bideari (ik. Mitxelena, 1953) jarraitu zioten, erronkarieraren azken hiztuna -Fidela Bernat anderea-1991n hil zen arte (testu eta material hauen guztien erreferentzietarako, ik. Camino, 2011: 101, 16. oh.).

Kronologiaren aldetik, Gaiarreren gutuna Bonaparteren bilketa lanen eta xx. mendekoen artean kokatzen da. Gutuna idatzi zen 1884ko urtean, hamabost urte pasa ziren Bonapartek jasoak zituela Erronkariko euskararen datuak: azken bilketa 1869an egin bide zuen, Euskal Herrira egindako azken bidaian, alegia. Espainiako egoera politikoa zela-eta Donibane Lohizunen geratu zen, baina bertara joanarazi zituen Erronkari, Zaraitzu eta Aezkoako hiztun bana (Yrizar, 1949: 103), ibar horietako hizkeren datuak biltzeko. Bestetik, Gaiarreren gutunaren eta Mariano Mendigatxak Azkueri bidalitakoen artean (1902. urtekoa da lehenengoa) 18 urte itxaron behar ditugu.

Tartean egoteaz gainera, Gaiarreren gutunak badu XIX-Xx. mendeetako gainontzeko lekukotasunetatik bereizten duen gehigarri bat: garai horretan hauxe dugu erronkarieraz helburu linguistikorik gabe idatzitako testu bakarra. Idazleak berez aukeratu du gutuna euskaraz idaztea, komunikazio egoeratik kanpoko arrazoirik gabe, nolabait esatearren; XVII. mendeko Migel Rosen gutunekin (eta Bonaparteren aurrekoa bide den Doctrina uscaraz testuarekin, apika) lotzeko modukoa dugu, beraz. Ezaugarri hau azpimarratu nahi dugu, erronkarieraren XIX. mendeko egoera soziolinguistikoari buruzko galdera berriak eragiten baitizkigu, ondorioetan adieraziko dugunez.

\section{JULIAN GAIARRE: BIZITZAZ ETA GUTUNAZ}

2015. urtean Julian Gaiarreren heriotzaren 125. urteurrena ospatu zen. Operaz edota euskaldun famatuez jakitun den orok ezagutuko du, izenez behintzat, abeslari erronkariarra, askorentzat azken mendeotan izan den kantari lirikoetarik onena. Haren biografiak xx. mendean zehar argitaratu dira, eta hari buruzko filmak ere egin dira, horietako batean Alfredo Krausek interpretatua, 1959an.

Julian Gaiarre Erronkari herrian jaio zen 1844an, laborari familia batean. Herriko eskolan oinarrizko ikasketak egin ostean, hamahiru urterekin eskola utzi behar izan zuen (nahiz eta maisuak gurasoekin hitz egin, umearen adimena zela eta; $c f r$. Salvoch, 2015: 27), etxean lagundu ahal izateko, eta artzain hasi zen herrian bertan. Bi urte

2 Cfr. Mitxelenaren (1953: 571) hitzok: «Sentíamos el más vivo deseo de recoger cuanto nos fuera posible de ese dialecto, si aún quedaba quien lo hablara» [etzana gurea, K. U.]. 
geroago, aitak Iruñera bidali zuen, bertan lagun baten dendatxoan saltzaile lan egin zezan. Askok diote bertan ezagutu zuela musika: banda bat denda aurretik pasa eta horri segika joan omen zen, denda utzirik (ibid.: 33). Honegatik lanetik bota omen zuten, eta Erronkarira itzuli zen. Horren ostean, errementari hasi zen Irunberriko forja batean, eta hamazortzi urte zituela hura utzi eta Iruñera itzuli zen, bertan ere errementari jarduteko.

Gaiarrek lan egin bitartean abesten omen zuen eta bere lagun batek, ahotsa entzunik, Joakin Maiak zuzentzen zuen Orfeón Pamplonés abesbatza sortu berrian izena ematea proposatu zuen eta zuzendariak lehenengo tenor postua eskaini zion. Horrela hasi zen solfeoa ikasten, Joakin Maia irakasle, Burlatako Hilarión Eslavaren metodoaren bidez (Salvoch, 2015: 47). Eslavak Gaiarre gaztea entzun eta Madrilgo kontserbatoriora joateko aukera eman zion 1865. urtean, beka batez. 1868an, bertan antolatzen zen kantu lehiaketan bigarren saria lortu zuen, 24 urterekin (ibid.: 65).

Orduan hasi zen hara eta hona, zarzuelak eta operak abesten, korista bezala. Hala ere, 1868an Espainian Seiurteko Demokratikoa hasi zen eta hurrengo urtean beka guztiak kendu zituzten, Gaiarre dirurik gabe utziz (Salvoch, 2015: 74). Kantutik bizitzeko bestelako diru-iturririk lortu ezinik, jakin zuen Gaztanbide zuzendari nafarrak talde liriko bat antolatuko zuela Ameriketara joateko, baina ez zuen Gaiarre hartu (ibid.: 77). Ezetza jaso izateagatik Iruñera goibel itzulirik, bertako lagun eta babesleak mugitzen hasi ziren, Milanera joan zedin, kantu ikasketak egitera. Honela, kontzertu batzuen bidez eta Nafarroako Diputazioaren diru-laguntza bat eskuratu ostean, Milanera heldu zen 1869 . urtean.

Hor hasi zen bere abeslari ibilbidea: Bolonian, Erroman, San Petersburgon, Moskun eta Vienan arrakasta lortu zuen; alabaina, benetako ospea 1876ko urtarrilaren $2 \mathrm{an}$ iritsi zitzaion, Milango La Scala antzokian La favorita opera abestuz, horrek munduko tenorrik onena bilakatu baitzuen askoren iritziz (Salvoch, 2015: 182). Ordutik aurrera munduko gainerako antzokiak zabaldu zitzaizkion: Londres, Buenos Aires, Alemania, Madril, Sevilla, Bartzelona, Napoles, Paris... garaiko kroniketan senza rivali, le Roi $d u$ chant bihurturik (urterik urte bere ibildearen berri jakiteko, ikus Salvoch, 2015). Hala ere, beti izan zuen Erronkari bere jaioterria gogoan: ahal zuen guztietan bertaratzen zen, bai udako oporraldiak igarotzeko, baita bereziki handik hurbil abesten zuenean ere; bertako bizi-baldintzak hobetzen ere ahalegindu zen: medikuntza-tresneria aurreratuena ekartzen zion ibarreko medikuari (Salvoch, 2015: 351 eta 654), herriarentzako frontoia eta eskola eraiki zituen (ibid.: 710), eta abar.

1889. urteko abenduan, gaixo egon arren, Madrilen Los pescadores de perlas opera abestea eskatu zioten, eta egin egin zuen, baina goiko nota bat ematera zihoanean ahotsa hautsi eta konortea galdu zuen. Honen ondorioz, depresioak jo zuen. 1890eko urtarrilaren 2an hil zen, 45 urterekin, Madrilen.

Gutunaren garaira itzulirik, 1884ko urriaren 20an heldu zen Gaiarre Bartzelonara (Salvoch, 2015: 525). Karreraren gorenean zegoen, La Scalan 1876tik aurrera ospe handia lortu zuenetik: munduan zehar kontzertuak eta operak antzezten zebilen, eta 
Bartzelonako Lizeoko kontzertu sasoiari hasiera ematera deitu zuten. Bertan zebilela, nonbait, izebari gutuna idazteko beharra sortu zitzaion, ziurrenik horren semea, Eugenio, bisitatzera joan zitzaiolako, eta ondo heldu zela esateko.

Ezin dugu jakin Gaiarrek beste testuren bat idatzi ote zuen euskaraz, tenorra hil ostean bere testamentu betearazleak, Julio Encisok, Gaiarreren azken borondatea beterik, Erronkariko etxean zen gutuneria intimoa erre baitzuen (Saiz Valdivielso, 1990: 7). Gutun hau da gorde zaigun bakarra, Gaiarreren gutunen artean ez, baizik eta Juanaren ondorengoen paperen artean baitzegoen ( $c f r$. Fagoaga, 1951: 13). Dena dela, Gaiarre eta euskara lotzen dituen elementu gehiago ere baditugu, tenorraren ilobetako batek idatzia baitu, Madrilgo teatroko entseguetan, Gaiarrek euskaraz hitz egiten zuela Erronkariko familiakoekin, gehienbat beste kantariei buruzko iritziak emateko. Honezaz gainera, kontzertuetako bis moduan «Gernikako arbola» abesten zuen (Fagoaga, 1951: 14). Besteak beste, aipatzekoa da Bartzelonako egonaldi hartan ere "Gernikako arbola» abestu zuela, "Círculo Vasco Navarro» delakoaren egoitzan (Salvoch, 2015: 527).

Bere txikitasunean, Gaiarreren gutuna lekukotasun garrantzitsua dugu, bai erronkarieraren erabilera idatziaz gogoeta egiteko, bai eta erronkarieraren beraren ezagutzarako ere, edizioaren oharretan zehar ageriko denez.

\section{EUSKAL GUTUNAREN EDIZIOA: ORAIN ARTEKOAK ETA GURE EDIZIO IRIZPIDEAK}

Gutun honen lehenengo berria Isidoro Fagoaga tenorrak eman zuen: Gaiarreren mireslea, Erronkariko abeslariaren historia berregin nahi zuen gizon eta musikari legez, eta horren dokumentu pribatuak aztertu nahiz familiarengana jo zuen. Familiak gorde zituen dokumentuen artean euskarazko gutun honekin topo egin zuen eta, garrantziaz jabetuta, argitara eman zuen Gernika aldizkarian (Fagoaga, 1951); ondoren, Fagoagak berak Retablo vasco liburuan ere eman zuen, gutun honek Gaiarrek euskaraz bazekiela frogatzen baitu (Fagoaga, 1959). Fagoagaren lehenengo transkribapen hark akatsak zituen, eta ondoko berrargitalpenak, Fagoagak egindakotik edateagatik nonbait, akats horiek zuzendu gabe atera ziren (Lekaroz, 2014).

Gaiarreren gutunaren argitalpenen ibilbidean bigarren heldulekua Irigarairen liburua dugu (Apat-Echebarne, 1974: 41). Berez Fagoagaren edizioari atxikitzen zaio, ikusiko denez, baina testuaren tradizioan aipatzea merezi duela uste dugu, edizio hau erabili baitzuen Yrizarrek erronkarierazko aditzaren inguruko liburuan (1992: 56). Ondoko mugarria Estornés Lasaren erronkarieraren hiztegian jarriko dugu (1997): Erronkariko uskaraz idatziriko lekukotasunen zerrenda egin, eta hauen artean hizpide dugun gutuna dakar, inolako sarrera eta iruzkinik gabe, Carta del famoso tenor navarro Julián Gayarre izenburuarekin (Estornés Lasa, 1997: 27). Edizio horrek aldaketa franko ditu Fagoagaren bertsioarekin alderatzen badugu, baina badirudi ez zuela gutunaren originala ikusterik izan: Fagoagaren akats asko errepikatzeaz gainera, hainbat aldaketa aieruz egindako zuzenketak direla ematen du. 
Laugarren izen bat gehitu behar dugu gutunaren edizioaren historian, eta hori Gorka Lekaroz ikertzailea da, Nafarroako euskarari buruzko blogean transkribapen berri bat eskaini baitu (2014), Erronkariko Julian Gayarre Museoan gordeta dagoen originala oinarri gisa erabilirik, eta haren argazkiak gehiturik, kalitate handikoak ez badira ere, tamalez. Lekarozek argi esaten du: "hau da nire ustez gaur egun Erronkariko Gayarre Museoan ikusgai dagoen gutunaren irakurketa zuzena, puntuazioa ere bere horretan emanik» (Lekaroz, 2014).

Gutunaren edizio berria eskaini nahi dugu lan honetan, orain arte egin diren irakurketak bilduaz, eta irakurleak gutuna ulertzeko beharrezko lituzkeen oharrekin hornituaz. Irakurketa egiteko Gorka Lekarozek bidalitako argazkiak erabili ditugu, originala zuzenean ikusi gabe ${ }^{3}$.

Gutuna paper puska batean idatzirik dago, bi aldeak betetzen dituela; argazkietan ikus daitekeenaren arabera ziurrenik lumaz idatzia da. Esan daiteke ez zuela plangintza berezirik izan idazteko orduan: bat-batean idatziriko testua dirudi, eta oro har argi idatzirik dagoen arren, batzuetan idatzi ahala zuzentzen du egindako akats mekanikoa. Dataturik eta sinaturik dugu, baina ez dago tokirik helbidea idazteko; beraz, pentsa dezakegu gutun luzeago batekin batera bidalitako oharra dela, eta euskal gutunaz hitz egitea baino, agian hobe litzateke euskarazko oharraz edo mandatuaz hitz egitea. Alabaina, lanean zehar tradizioak ezarri dioen gutun izena erabiliko dugu.

Ez dugu edizio paleografikoa egingo, testukritikak interpretatiboa deitzen duena baizik (ik. Roncaglia, 1975: 81); horrek esan nahi du testuaren alderdi hutsalak albo batera utzirik, garrantzitsuetan jarriko dugula begia. Horrela, ez dugu originalaren lerro banaketa markatuko. Puntuazioa, letra larri eta xeheen erabilera eta hitz banaketa eguneratuko ditugu, gaur egungo ediziogintzan ohikoa den bezala. Lerroak zenbatu ditugu, horietaz baliatuz markatuko baititugu ondoko oharrak. Dena dela, kontserbatzaile jokatuko dugu eta, testua zuzendu beharrean, oharretan aurkeztuko ditugu irakurketa arazoak eta zuzenketa proposamenak.

Honezaz gainera, orain artean egindako irakurketa ezberdinak, garrantzitsuenak bederen, berariaz jasoko ditugu gurean, testuak izan dituen ulermodu ezberdinak bildurik erakusteko. Honetarako, aparatu kritiko bat atonduko dugu, goian aipaturiko edizioak oinarri ${ }^{4}$ izanik, Fagoagarena (F), Irigarairena (I) eta Estornés Lasarena (E).

3 Webgunean agerturikoak baino kalitate hobeko argazkiak eskuzabal eskaini dizkigu Gorka Lekarozek. Bihoazkio hemendik nire eskerrik beroenak Nafarroako euskara zaharraz eta bere historiaz hainbeste arduratu den ikertzaile honi.

4 Interneten testuaren beste edizio batzuk aurki daitezke; hauek oro har Fagoagaren edo Irigarairen edizioaren kopiak dirudite eta, honegatik beragatik, codex descriptustzat jo eta gure aparatu kritikora ez ekartzea erabaki dugu, larregi ez luzatzearren. 
Aparatua negatiboa izango da, hau da, gure ediziotik ezberdin diren irakurketak bakarrik jasoko ditu (cfr. Blecua, 1983: 148) $)^{5}$.

Testuaren ostean ohar paleografikoak ezarri dira, testua irakurtzean aurkitu ditugun arazoak eta horiei buruzko azalpenak bildurik. Ondoren aparatu kritikoa dator eta, honen atzetik, hizkuntzazko eta bestelako oharrak, batez ere irakurleak testua egokiro uler dezan beharrezkotzat jo ditugun hizkeraren gaineko zehaztapenak.

\section{EDIZIOA}

Barcelona, 19 diciembre 1884

Ene tia Juana maitia:

Eugenio sin da arro onqui. Quemen gaude anisco onqui guziac, eta ori, nola dago? Nai dia sin cona ichasoaren ecustra? Anisco andi da, tia Juana; nai badu nic dud anisco deuri orrentaco, vidagearen pagataco eta quemenco ostatiaren pagataco. Eztu eguiten quemen ozic batrere. Chaten dugu quemen anisco onqui eta guero artan dugu iror nescasci postretaco, eta gazte eta pollit.

Ha! Cer vizia! Tia Juana maitia, amar urte chiquiago bagunu...! Gorainzi guzientaco eta piyco bat nescachi pollit Erroncarico guziat.

\section{Ohar paleografikoak}

3 arro: Aurreko editore guztiek arro garbi irakurri duten arren, irakurketa ohar pare bat egin behar dira. Hitz amaierako -o guztiak biribil perfektuak dira (Eugenio, anisco ), baina hitz honetan marra bat ageri da biribilaren erdian, hitz barruan ageri diren $o$ letretan ikusten den lotura-marra balitz bezala (cfr. onqui, erroncarico). Bestetik, Gaiarrek bi $r$ mota erabili zituen: batetik, moldiztegikoaren antzeko marrazkia duena (ori, orrentaco...) eta bestetik bere $<$ z >ren oso antzekoa dena (erroncarico, amar...). Hitz honetan bigarren motakoak erabiltzen dituenez, arro irakurketaz gainera "azzo, "arzo edo "azro ere posible lirateke: hauetatik guztietatik lehenengoak (azzo) bakarrik luke zentzurik, baldin eta $<$ zz> grafia afrikatua adierazteko baliabidea dela suposatzen badugu eta, beraz, atzo idatzi nahi zukeela (Eugenio xin da atzo onki). Alabaina afrikatuaren beste adibidean (ozic) eta Erronkariko beste lekukotasunetan (ik. Gómez, 1991: 393) ere baliabide hau ez erabiltzeak arro hobestera garamatza.

5 Lekarozen (L) transkribapena ere erkatu dugu gurearekin, baina bion irakurketak bat datozenez, ez da aparatuan ageri. 
5 quemenco: $c$ azpian zerbait dago, $-t$ ?

6 ostatiaren: st azpian zerbait dagoela dirudi.

7 artan: Bigarren $a$-ren azpian zerbait dela dirudi, eta arten ere irakur daitekeela (ik. ohar azalgarria).

7 dugu: Hitzaren amaieran zirrimarra bat dago, dugun?

7 postretaco: $s$ azpian zerbait dagoela dirudi.

9 piyco: Aurreko editoreen irakurketa mantendu dugu, baina pigco irakurtzeko aukera ere badago, $i$ eta $c$ arteko letra gazte hitzaren $<$ g $>$ tik oso hurbil baitago kaligrafikoki. Gure ustez erdal pizco-ren aldaera palatala denez ("pixko; $c f r$. ohar azalgarria), eta [ $\left.\int\right]$ adierazi behar duela suposatu dugunez, agian pigco irakurketa hobeto legoke; baina ez da halakorik inoiz deskribatu euskal grafiaren historian.

\section{Aparatu kritikoa}

119 diciembre] 19 de diciembre E 3 Eugenio] Eugenia FIE II arro] arro(nt) $I \|$ onqui] ongui $F I \|$ onqui] ongui $F I \|$ guziac] guciac FIE 4 nai dia] nain din FI: nai din $E$ II andi] andia FIE 5 deuri] deiru FIE II orrentaco] orentaco FIE II pagataco] pagateco $F E \|$ eta] ø FIE \| quemenco] quemengo FIE 6 eztu] ezdi $E$ \| chaten dugu] chaten degu F: chatan degu $E 7$ onqui] ongui $F I \|$ nescasci] nescache FIE II pollit] polit $E 9$ Erroncarico] Erroncari E.

\section{Ohar azalgarriak}

2 Tia Juana: Julian Gaiarreren izeba dugu, Eugenioren ama (cfr. 3 Eugenio); Juana Barrena dira emakume honen izen-abizenak (Fagoaga, 1951: 13).

2 maitia: XIX. mendeko (Gomez, 1991: 401) eta Xx. mendeko erronkarierazko lekukotetan (Mitxelena, 1954: 625) $e+a>i a$ aldaketa erregularra da.

3 Eugenio: Julian Gaiarreren lehengusua da, gutunaren buruan ageri den tia Juana-ren semea (Fagoaga, 1951: 13). Fagoagaren datuen arabera, egiantz handiz tenorraren testamentuan aipatzen den Eugenio Garjón y Barrena (Salvoch, 2015: 865) litzateke.

3 sin: 'jin, etorri' (ik. 4. lerroan ere), erronkarieraz [S] txistukari sabaikariaz ahoskatzen zen $j$-ren ondorengoa ( $x$ in; cf. $F H V \S \S 9.2$ eta 10.10), eta hots hori idazteko Gaiarrek $<$ s $>$ darabil, honetan eta anisco (3) hitzean bezala (baina ik. 6 chaten). Bonaparteren funtsetan gordetzen den dotrinan (agian Erronkari herrikoa bertakoa; Gómez, 1991: 379), <s> grafia bera aurkitzen dugu hots sabaikari hau adierazteko (ibid.: 394). 
3 arro: Ez dirudi inolako erlaziorik duenik Hegoaldeko zenbait hizkeratan harro den hitzarekin, eta hapaxa dela esango genuke, testuinguruaren arabera 'oso' edo 'guztiz' esanahia lukeen aditzondo bat, agian. Fagoagak arrunt hitzaren aldaeratzat hartu zuen: «falta la $n t$ de arront de uso corriente en el Bidasoa» (Fagoaga, 1951: 14) ${ }^{6}$, akats edo aldaeratzat joko lukeen argitu gabe. Arrunt «totalmente, muy» (OEH, s.v. arrunt II) hitzaren aldaeratzat harturik, $t$ gabeko aldaera batetik letorkeela pentsa dezakegu (biarnesak arroun forma du, nonbait; ik. Agud; Tovar 1989, s.v. arront), eta $n$ galdu, agian azken bokala sudurkarituz'. Baina erronkarieraren bokal sudurkariak bokal arteko testuinguruan baino ez ziren sortu ( $c f r$. Egurtzegi, 2014: 159 e. hh.), eta beraz ezin da $n>\varnothing$ arauan inola ere pentsatu; ondorioz, azken bokala sudurkaria izatea ezinezkoa litzateke hitz honetan. Hau honela, akatsean pentsatzea dateke zuzenena, gogoan izanik ohar paleografikoan aipaturikoa: hots, o horrek lotura marra duela, hitz bukaera ez balitz bezala: agian $n$ edo $n t$ idatzi gabe utzi zuen Gaiarrek, presaka ari edo, Fagoagak proposatu bezala.

3 onqui: Erronkarieraren eta zubereraren ezaugarri ezaguna da $n$ eta $l$ osteko herskari ahoskabeak (cfr. FHV: 1 12.6; Camino, 2011: 102) ${ }^{8}$, eta halantxe ageri zaigu Gaiarreren gutuneko adibide guztietan: orrentaco (5), quemenco (5), eta guzientaco (9).

3 quemen: 'hemen' (ik. 4 cona). Iparraldeko hizkeretan $b$ - eta Hegoaldekoetan (hasperena galduta) ø- duten erakusle eta adizlagunek ( hau, hona, hemen) kontsonante belar bat garatu zuten Nafarroako hainbat hizkeratan, $g$ - aezkeran eta hegoaldeko goinafarreran ( $g a u$, gona, gemen) eta $k$ - erronkariera eta zaraitzueran (kau, kona, kemen; Mitxelena, 1954: 632 eta Gómez, 1991: 404).

3 anisco: 'anixko, oso'. OEHk (s.v. anixko) txistukari sabaikari zein apikaridun adibideak bildu ditu, eta bietara irakur daiteke gure adibidean, Gaiarrek $s$ erabiltzen baitu dela apikaria ( $c f r$. ichasoaren, postretaco), dela egun $x$-z idazten dugun hotsa adierazteko, ikusi dugunez ( 3 sin). Dena dela, erronkarieraz anixko ahoskera espero dugu, txistukari sabaikariz (ik. Pagola et al., 1997: 339), eta horrela irakurtzea proposatzen dugu.

3 guziac: 'guztiak'. Erronkarieraz guzu forma espero genuke mugagabean («En roncalés guzu aparece documentado ya desde el s. XVI»; OEH, s.v. guzti), baina $u$ + a bokal bilkurak hainbat emaitza ditu erronkarieraz: honetan (eta 6 ostatiaren) dugun -ia-k Urzainki edo Erronkari herrian (hots, Gaiarreren sorterrian)

6 Irigaraik Fagoagaren irakurketa hobetsi eta parentesi artean gehitu du $(n t)$.

7 Alabaina, OEHk (s. v. arrunt) ez du ez $t$ ez $n t$ gabeko aldaerarik lekukotzen euskaraz.

8 Oro har arkaismotzat jo izan da ( $c f r$. Mitxelena, 1964: 32 eta Camino, 2011: 102); hala ere, berriki dudatan jarri da (dagoeneko Mitxelenak iradoki zuenez, ik. $F H V \S 18.10$ ), eta berrikuntza izan zitekeela proposatu (Lakarra, 2011: 206, 136. oh.). 
kokatzen du testuaren hizkera, Bidankoze (-iua) eta Gardetik (-ioa) aldenduz (cfr. Mitxelena, 1954: 626).

3 ori: 'berori'. Gaiarrek errespetuzko tratamendua darabil izebarekin ( $c f r$. Alberdi, 1996: 121 e.hh). Formaren aldetik, ez da askorik aldentzen gainerako erronkarierazko lekukotasunetatik ( $c f r$. Mitxelena, 1953: 594; Pagola et al., 1997: 274). Izan ere, aurretik $k$ - duten formak (kori; cfr. 3 quemen) eta øhasierakoak (ori) banaketa osagarrian daude (cf. 5 orrentaco): lehenengoak erakuslea adierazten du, eta bigarrena izenordain legez erabiltzen zen ( $\mathrm{Mi}$ txelena, 1954: 632).

4 dia: 'dua', - a galdera marka erabiltzen du, Ekialde zabal batean erabiltzen den marka: zubereraz eta erronkarieraz gainera Zaraitzun, Nafarroa Beherean eta Lapurdin ere ageri da marka hau (ik. Camino, 2011: 125) ${ }^{9}$. Horrezaz gainera, aipatzeko da $u+a>i a$ bilakabidea, Erronkari Gaiarreren sorterrikoa, ikusi bezala (ik. 3 guziac).

4 cona: 'hona', ik. quemen eta orrentaco.

4 ichasoaren icustra: Ekialde zabaleko euskaran (Iparraldekoan eta Nafarroa Garaiko ekialdeko hizkeretan, behinik behin) TOGEN egitura baliatzen dute gaur egunera arte (Padilla-Moyano, 2013: 385; eta hedatuago zegoen antzina, Camino, 2011: 104), gure testutxoan ikus dezakegun bezala (cfr. vidagearen pagataco eta ostatiaren pagataco). Antzina orokorra bide zen (cfr. Lakarra, 1996: 191) egitura honetan aditz izenaren bidez egindako menpeko perpausetako objektu zuzena genitiboan ageri da, beste hizkerek absolutiboan ematen duten bitartean (ik. Padilla-Moyano, 2013).

4 icustra: 'ikustera'. Halako sinkopak ezagunak dira Nafarroa Garaiko hizkera gehienetan, indar gehiagoz edo gutxiagoz $(F H V \S 8.5)$; alabaina, ipar-ekialdeko Erronkarin eta Zaraitzun du indarrik handiena: «La caída de vocales, sobre todo en interior de palabra, es un fenómeno característico que el ronc[alés] tiene en común con el sal[acenco] que acaso lo presente aún en mayor grado» (Mitxelena, 1954: 627).

4 andi da: Ezaguna da ekialdeko hizkeretan mugagabeak mendebaldean baino sendoago iraun duela (cfr. Manterola, 2006), eta ezaguna da, halaber, atributua dela mugagabea luzaroen atxiki duten osagaietako bat, are mendebaldean ere $(c f r$.

9 Orain arteko bertsioetan din irakurtzen bazen ere, irakurketa horren arazoez Yrizar (1992: 56) konturatu zen aieru onarekin: «Hay una frase que desentona del resto de la carta. La citada frase es la siguiente: Nain din sin cona ichasoaren ecustra? (Nai dun xin honat..., aclaró Irigaray). La forma verbal din (dun) corresponde al hika femenino, mientras que el resto de la carta no está escrita con esta familiaridad, incluso contiene expresiones correspondientes a berori, como la frase Nai badu nic dud anisco deiru...». 
Mitxelena, 1979: 301); hau honela, egungo hiztun askorentzat arrotz bide den joskera hau, Gaiarreren gutunak diosku arrunta zela XIx. mendeko Erronkariko hizkeran.

5 dud: 'dut'. Singularreko lehen pertsonaren marka adizki amaieran ageri denean erronkarierak herskari ahostuna mantendu du. Bonapartek $-d$ eta $-r$ artekotzat du amaierako hots hau (ik. Yrizar, 1992: 6- 11), baina badirudi ezberdina zela hizkeraren arabera: Bidankozeko aldakian (Erronkari hiribildua barne) $d$ eta Uztarrozekoan $r$ ahoskerek nahiko ziurrak dirudite (Mitxelena, 1954: 633 eta Gómez, 1991: 405; cfr. baita Camino, 2011: 109 ere). Agerian denez, Gaiarre Bidankoze eta Erronkarirako deskribaturiko usadioari atxikitzen zaio; eta Mitxelenak egin bezala: «me parece pues más seguro dar crédito al sentimiento que Hualde Mayo [Gaiarre, hemen] tenía de su dialecto materno que al testimonio de Bonaparte» (Mitxelena, 1954: 633).

5 deuri: 'diru'. $i$ gaineko puntuak salatzen duenez, horrela irakurri behar da, erronkarieraz deiru ere lekukotzen bada ere (cfr. Mitxelena, 1953: 603). Aldaera hau ez da ezezaguna ( $F H V \S 4.7$; Pagola et al., 1997: 348), eta Gaiarreren hizkera Bidankozekotik aldentzen du, herri honetan deiru omen zegoelako ( $F H V \S 4.7)$.

Bestalde, hitz honek inoiz diptongo sudurkaria izan zuen (ik. FHV § 5.10; $c f r$. gazt. dinero, lat. denarium), baina testuan ez da idatziz ezaugarri hau islatzen, XIX. mendeko beste idazleek bezala (cfr. Gómez, 1991: 392). Dena dela, aipatzekoa da hitz honen ahozko lekukotasunetan ( $c f r$. Mitxelena, 1953: 603 eta Mitxelena, 1954: 616) ez dela deuriren sudurkaritasunaren berri eman.

5 orrentaco: 'berorrentzat'. Erronkarieraz erakusleek $k$ - eta izenordainak $\varnothing$ daramatela esan dugu (ik. 3 quemen eta 3 ori); hau honela, hemen berorikako izenordaina dugu mugatzailea izatekotan ${ }^{10}$ *correntaco esperoko baikenuke (cfr. correngatic; Pagola et al., 1997: 265).

Destinatibo markari buruz (cfr. 9 guzientaco; ik. baita HH. EE., 1987: 511 eta Pagola et al., 1997: 262), ekialdean -endako atzizkia Zuberoan, Nafarroa Beherean eta Nafarroa Garai gehienean erabiltzen da egun (Zuberoa eta Erronkarin -entako, cfr. 3 onqui $)^{11}$, Lapurdin eta Behe Nafarroaren mendebaldean bien arteko lehiak dirauen bitartean (EHHA, 1085. mapa; cfr. Zuazo, 2008: 247).

5 vidagearen: 'bidaiaren'. Grafia etimologikoa dugu $<\mathrm{v}>$; eta $<$ g $>$ ohikoa dugu garaiko testuetan frikari belarea idazteko (cfr. Gómez, 1991: 392). Aldaerari dagokionez,

10 Interpretazio (ia?) ezinezkoa da diru horrentaco irakurketa egitea, aniskok mugagabe eskatzen duelako betiere. Hala ere, argitzea beharrezko izan zaigu, itzulpen zenbaitetan interpretazio honekin aurkitu dugulako.

11 Nafarroatik kanpo ere, Deba ibarrean, Durangaldeko hizkera batzuetan eta Goierriko mendebaldean aurki dezakegu. 
OEHk hauxe diosku (s.v. bidaje): «bidaje (además de un ej. de Leiçarraga) se encuentra en textos suletinos desde mediados del s. XVIII, y en guipuzcoanos desde la segunda mitad del XIX (tbn. en el roncalés Mendigacha)».

6 ostatiaren: 'ostatuaren'. ik. 3 guziac.

6 ozic: 'hotzik'. Gaiarrek ez du afrikazioa grafikoki adierazten (cfr. 9 Gorainzi). XIX. mende hasierako Erronkari inguruko lekukoek egoera bertsua erakusten dute, hain zuzen Bonaparte printzea heldu eta hauek bereizi behar zirela eta nola bereizi behar ziren gaztigatu arte (ik. Gómez, 1991: 393, 27. oh.).

6 batrere: 'batere'. Erronkarieraz batre eta batrere aldaerak lekukotzen ditu OEHk (s.v. batere), eta zehazten du Mendigatxa batrere formaz bakarrik baliatzen dela, gure testuak dakarren beraz, alegia. Dudarik gabe baterere formaren aldaera sinkopatua da ( $c f r$. «Hemos encontrado algún ej. de baterere en Etcheberri de Ziburu, Beriayn y Lizarraga de Elcano»; OEH, s.v. batere).

6 chaten: 'jaten'. Forma hau irakurtzeko bi aukera genituzke, edo testuko gainerako $<$ ch> guztiak bezala (chiquiago, ichasoaren; ik. 9 nescachi) afrikatu irakurtzea (txaten) edo, erronkarieraz espero dugun bezala (beti xan lekukotu baita) frikaria izatea. Frikaria izateko, $<\mathrm{ch}>=\left[\int\right]$ frantses grafiaz baliatu dela pentsatu behar, testuko beste adibideetan ez bezala $(c f r .3 \sin )$. Ez da ezinezko, Gaiarrek frantsesez zer edo zer jakin behar zuelako ${ }^{12}$ eta, gainera, Hualde Mayok ere lekukotzen duelako (gachqui, gaichtuetaric; Camino; Gómez, 1992: 504-5) 13. Hala eta guztiz ere, Gaiarre gaztelaniaz hezia behar zuen izan eta, beraz, zaila dirudi -oharkabeko hutsean pentsatu nahi ez badugu- frantses grafia erabiltzea, zailago gainerakoetan <ch> espainolaren erara erabiltzen duela ikusirik. Beraz, errazago dirudi hemen ere $<\mathrm{ch}>$ afrikatua izatea.

Txaten irakurketan bermatzen gaitu Arakistainen lekukotasunak: 1746an Erronkarin bilduriko hitz zerrendan afrikatuz idazten ditu chauce 'salto' eta chauci, chaucitu 'saltar' (Arakistainek berak xin, siyn 'venir' dakar). Honek eta Gaiarreren lekukotasunak batera elkar bermatzen dute (bien artean mende bateko tartea egon arren), Erronkarin hitz hasieran afrikatze bat gertatzen

12 Frantses irakurria bederen, bere errepertorioan frantsesez idatziriko operak bazituela ezaguna baita: L'Africaine, Le prophète... (cfr. Hualde [s. d.]: 2).

13 Dena dela, testuinguru fonetiko eta morfologiko berezi batean dira gachqui eta gaichtuetaric formak: herskari aurrean, silabaren kodan, eta afrikatuaz amaitzen den berba baten [hitz + atzizki] egituraren mugan. Adibideok azaltzeko $<\mathrm{ch}>=\left[\int\right]$ erlazioa proposatzea baino - Hualdek berak $<$ ss $>$ baliatzen zuen nagusiki egungo $x$ adierazteko (are testuinguru honetan ere: gaisstuetaric, gaissto)- bide errazagoa dirudi grafia etimologikotzat hartzea, oinarriaren txistukari afrikatua iradokiz. Hualde Mayok berak dakarren ssinetstia (i.e. ssinets + tia) formaren kide lirateke gachqui eta gaichtuetaric, eta ez da antzeko adibiderik falta euskal tradizioan: $c f r$. hitzkuntza forma Leizarraga, Axular, Iztueta edo Archuren obretan eta gaitzto Otxoa de Arinen dotrinan (OEH, s.vv. hizkuntza eta gaizto). 
zela erakutsiz, esanahi adierazgarri batekin, agian ${ }^{14}$. Halere, geroko ahozko lekukotasunen arabera (txan bezalakorik ez da xx. mendean zehar bilduriko testigantzetan; cfr. Mitxelena, 1954: 629 eta Gómez, 1991: 394-5), afrikatzea galdua zen edo ez zen hain erraz gertatzen, ez behintzat ikerketetan islatzeko bezainbestetan.

7 artan: 'hartzen'. Fagoagak «artean, bertan» ulertu zuen, baina egokiago iruditzen zaigu hartu aditzaren aditz izentzat hartzea. Izan ere, Garde eta Urzainkiko (eta Erronkariko) euskaran -(e)tan atzizkia erabiltzen zen -tu partizipioen aditzizenak sortzeko (Gómez, 1991: 410; -etan atzizkiaren jatorrirako, Urgell, 2006: § 2.3). Ez dago azterturik -(e)ta eta -te atzizkien arteko banaketa, nonbait (Gómez, 1991: 410, 126. oh.), baina gutunak erakusten digu, bere txikitasunean, Gaiarrek $n$ amaieradun partizipioekin $-t e(n)$ atzizkia baliatzen zuela (chaten, eguiten) eta $-t u$ partizipioekin -ta(n) (artan, pagataco).

7 iror: 'hiru'. Amaierako - $r$ arkaismoa da, ekialdean orain arte gorde dena $(F H V \S$ 17.7). Bigarren bokalari dagokionez, erronkarieran irur / iror, aukera biak aurkitzen dira XIX. mendean zehar, eta ondoko mendean hasiko zen herri bakoitza biotatik bat aukeratzen, hizkera galdu ahala (Gómez, 1991: 396 eta Mitxelena, 1954: 617; cf. Pagola et al., 1997: 360). OEHren arabera (s. v. hiru) aldaera hau erronkarieraz bakarrik lekukotu da.

7 nescasci: Gómezek <sc > grafia aurkitu du afrikatua adierazteko berak argitaraturiko dotrinan, sausci 'jautsi' adibidean (Gómez, 1991: 395), baina gure adibideko irakurketa ez da arazorik gabekoa, <sc>k neskatsi edo neskatzi aldaera iradokiko bailuke, alegia, aldaera ezezagun bat (cfr. OEH s. vv. neskaxe, neskatxa, neskatxi $)^{15}$. Hau honela, akatsa izateko aukera asko ditu, aurreko <sc>aren eraginez hain zuzen, eta "nescachi zuzendu beharko litzatekeela (cfr. 9. lerroan nescachi).

7 postretaco: 'postretarako'. Prolatiboaren -tako atzizkia izan daitekeen arren ${ }^{16}$, hemen postretaco nekez uler daiteke prolatibo bezala, eta gehiago dirudi - $k o$ morfemaren erabilera destinatiboa, denborazko baliotik hurbil.

$14 C f r$. «En posición inicial [...]. En los [dialectos] orientales hay unas pocas variantes expresivas con $t z-$ : sul[etino] tzintzárri 'campanilla', sal[acenco] tzimur 'arrugado', ronc[alés] Uztárroz tzuntzur 'garganta'» (FHV $\S 14.6)$.

15 EKCean bakan da neskatsa aldaera; alabaina, corpus honetan ageri diren -tsa adibideak azaltzeko orduan, arrazoi filologikoak medio, proposa genezake adibideok akatsak izan daitezkeela.

16 - (a) rentako destinatibo marka (ik. 5 orrentaco) duten mintzoetan -tako ageri da prolatiboan, -tzat ere ezaguna izan arren: honela Zuberoan (Camino, 2011: 134) eta Erronkarin -tako espero dugu, azken hizkera honetan Mendigatxa lekukotzen duenez (ibid.: 134, 130. oh.; ik. Pagola et al., 1997: 263). 
7 pollit: (cfr. 9. pollit) Bustidura adierazgarriarekin (cfr. FHV 10.2 eta Oñederra, 1990: 57 e. hh.), erronkarieran lehendik ere ezaguna zenez (Mitxelena, 1954: 637).

8 chiquiago: 'gutxiago'. Adiera hau espero izatekoa da erronkarierazko testuetan (ik. Mitxelena, 1953: 595), eta OEHk iradokitzen digunez (v. s. txiki 6), euskalki honetan bakarrik.

8 bagunu: 'bagenu'. $i-u>u-u$ asimilazioa ezaguna da Erronkarin (cfr. FHV § 3.4); ekialdeko beste mintzoekin (zuberera eta amikuzera) partekatzen duen ezaugarria dugu ( $c f r$. Camino, 2011: 117), azken hauek $i$-rekin bakarrik egiten badute ere. Dirudienez, hau bezalako *edun-en adizkietan asimilazioak indar bereziki handia izan du Erronkarin (Mitxelena, 1954: 619).

8 Gorainzi: Ikusi denez, testu honetan $<$ z $>$ grafiak afrikatua zein frikaria adierazten du (cf. 6 ozic); beraz, ozen + txistukari taldeetan ezin dugu ebatzi txistukaria frikaria ala afrikatuaren den ( $c f r . F H V \S 14.6$, (d) azpiatala). Erronkarieraren beste (ahozko) lekukotasunak ikusita, baina, afrikatua dateke (ik. Gómez, 1991: 407).

9 guzientaco: 'guztientzat'. ik. 3 guziac eta 5 orrentaco.

9 piyco: Hitz honi buruz Fagoagak (1951: 14) hauxe diosku: «el piyco es mucho más discreto y galante que el pellizco con el que nuestro pícaro autor no quiso confundirlo", hau esateko dituen argudioak adierazi gabe. Fagoagaren ondoren «pellizco» legez ulertu izan da hitz hau, bada. Hapaxa dugu euskaraz, baina pizco 'pellizco' ezaguna da gaztelaniaz eta Aragoi Garaian pizcar 'pellizcar' lekukoturik dago (ik. DCECH, s. v. pellizco); beraz, honen aldaera adierazgarria dateke pixko, gazt. pizca > eus. pixka eman duela kontuan izanda. Alabaina, azaldu gabe geratzen zaigu grafia, nolatan $[\delta]$ adierazteko $<y>$ erabiltzen duen (ik. ohar paleografikoa).

9 nescachi: OEHren arabera (s.v. neskaxe) erronkarierazko testuetan neskaxi edo neskaxe espero bada ere, Mitxelenak (1953: 581) argitaraturiko erronkarierazko materialetan neskátxi forma, afrikatuaz, badela ikus dezakegu. Adibide honek Gaiarreren testuan $<$ s $>$ / <ch $>$ grafien arteko guztizko oposaketa delako ideiarekin bat egiten du; honela, nescasci formaren <sc> idazte-akatsa dela indartzen da (ik. 7 nescasci), eta chaten formaren txaten irakurketa sendotu (ik. 6 chaten).

9 nescachi pollit Erroncarico: Leku-genitiboa izenaren ostean ageri da. Egitura hau ohikoa da testu zaharretan (ik. Reguero, 2013: 449 e. hh; cfr. baita Ulibarri, 2015: § 4.2.4.4).

9 guziat: 'guztirat'. Adlatiboa datiboaren ordez: piyco bat nescachi pollit Erroncarico guziari/guzier. Datiboaren eta leku-denbora kasu zenbaiten (adlatiboa) arteko 
gurutzaketak ezagunak dira testu zaharretan ${ }^{17}$, eta erronkarieraren deskribapenetan aipatzen da solezismo hau (HH. EE., 1987: 515).

Adlatiboaren -rat forma ekialde zabalean aurkitzen da, baita Zuberoan eta Erronkarin ere (Camino, 2011: 133) ${ }^{18}$. Besterik da bokal arteko $r$ bakunaren galera; zubereran duen indarragatik askotan aipatzen den ezaugarria da, XIX. mende erdialdean datatua (ibid.: 128), baina ez da Erronkariko euskararen ezaugarritzat hartu, oro har honelako galerak nonahi gerta baitaitezke: «La debilidad de $r$, si en ninguna parte parece haber llegado a la desaparición total como en suletino, se manifiesta sin embargo en muchos lugares» (FHV § 17.2).

\section{ONDORIOAK}

Gutun honek, bere txikitasunean, erronkarierari buruzko hainbat datu dakar, lanean zehar ikusi denez: erronkarieraren ezaugarriei buruz genekiena sendotzera etorri da, batetik; baina galdera berriak egiteko aukera ere eskaini digu, bestetik. Alabaina, azterketa filologikoak ikuspegi soziologiko edo soziolinguistikotik ere zenbait gogoeta egiteko aukera ematen du, grafiaren azterketak bederen horretarako oinarri den heinean.

Oro har, gutunean diren ezaugarriak dialekto galduaren bereizgarrietako batzuk gogoratzeko baliatu ditugu; honela, maitia-k adibidearen bidez ikus dezakegu $e+a>i a$ egiten zela erronkarieran; eta bagunu adibidean $i-u>u-u$ asimilazioa ere bazela. Era berean, erakusleetako hasierako $k$ - (quemen, cona), $n$ (eta $l$ ) osteko herskari ahoskabea (onqui, orrentaco) eta sinkopak (ecustra) lekukotzen ditu. Morfologian, erronkarieraz gainera ekialde zabalagoan aurkitzen den galderetako $a$ atzizkiaren alerik ere bada (dia). Berorikako izenordearen formak ditugu ori eta orrentaco, eta atributua mugagabean agertzen zaigu (andi da), ezaugarri biak Erronkariko beste lekukoetan ere badirenak. Lexikoan, erronkarierazko aldaerak dira deuri 'diru', vidage 'bidai', batrere 'batere' eta iror 'hiru', eta euskalki berekoa genuke txiki 'gutxi' esanahiarekin erabiltzea. Erronkarieraren barnean, berriz, Erronkari herriko euskarara hurbiltzen gaituzte ostatian eta dia adibideen bidez lekukotu dugun $u+a(>* u i a)>i a$ ezaugarria eta adizkietako lehenengo pertsonaren $d$ marka izatea $(d u d)$.

Ezaugarri ezagun hauekin batera, berezi gertatu zaizkigun zenbait forma ere aurkitu ditugu, arro ('arrunt'?) eta piyco ('pixko'?) hapax lexikoetatik hasita. Dena dela, ororen gainetik chaten forma gertatu zaigu berezien, “ $j$-ren ahoskera afrikatua iradokitzen

17 Cfr. Euskal Herriko beste muturrekoa den Dotrinazko Sermoitegia (ca.1770) obraren adibidea (ap. Ulibarri, 2015): Pregunte onetara emongo dodas respuesta bi (1. sermoia).

18 Pagola et al.-ek (1997: 261) ematen dituzten deklinabide marken deskribapena ikusita, -ra da atzizki bakarra; hala ere, Caminok (2011: 133, 126. oh.) dakarren bezala, Hualde Mayok badu urrinarat bezalako adibiderik ebanjelioaren itzulpenean. 
baitu. Orain arte aipatu gabea da ezaugarri hau erronkarierari buruzko bibliografian, baina zuzenean lotuko litzateke Arakistainek 1746an bilduriko (ik. eranskina) chauce 'salto' eta chauci, chaucitu 'saltar' adibideekin, nonbait.

Gutuntxo honek dakarkigun galderarik handiena, baina, beste bat da: Gaiarrek euskaraz idazten ikasi zuen, ala idazten jarri zen, besterik gabe? Eta galdera honen ifrentzuan legoke ea izebak euskaraz irakurtzen ikasi ote zuen, ala besterik gabe irakurtzen ikasi zuen. Testu honek gutxieneko kontuan erakusten digu orduko erronkariarrentzat ez zela hain zaila euskaraz idaztea eta irakurtzea, baina oraingoz ezinezko zaigu erantzutea ea propio euskaraz idazten eta irakurtzen ikasi zuten. Ikerketa berrien akuilu izan daiteke, dena dela: badakigu Gaiarrek (eta Mendigatxak, nonbait; cfr. Estornés Lasa, 1984) oinarrizko hezkuntza jaso zuela herriko eskolan bertan, eta ez zuen Erronkarin (eta Nafarroan?) besterik ikasi, antza denez. Nafarroako eskolan xviII. mendetik aurrera, bederen, erdaraz bakarrik egiten zenez derrigor (ik. Urgell, 2016: § 1.2.1), eskola baino eliza dateke erantzuna aurkitzeko gunerik egokiena, dotrina irakasteko garaian. Alde horretatik datu gehiago biltzerik dagoen galdetzen diogu gure buruari (dotrina euskaraz irakasten zuen parrokorik edota euskararekiko eskuzabala zen maisurik ote zegoen); bitartean, gutuntxoaren hizkeraren bizitasunarekin gozatzea besterik ez dugu. 


\section{BIBLIOGRAFIA}

Agud, M.; Tovar, A., 1989, «Materiales para un diccionario etimológico de la lengua vasca (IV)», ASJU, 23 (1), 133-203.

Alberdi, J., 1996, Euskararen tratamenduak: erabilera, Bilbo, Euskaltzaindia, «Iker», 9.

Apat-Etxebarne, A. [A. Irigarai], 1974, Una geografía diacrónica del euskara en Navarra, Pamplona, Ediciones y Libros.

Azkue, R. M., 1931, «Particularidades del dialecto roncalés», Euskera,12, 207-406.

Bilbao, G., 2006, «Joanes Etxeberri Sarakoaren saiakera lanak eta latina ikasteko gramatika: edizioa eta azterketa», UPV/EHU-ko doktorego tesi argitaragabea.

Bilbao, G. et al., 2016, «Etxart eta Rosen gutuneria: edizioa eta azterketa», eskuizkribu argitaragabea.

Blecua, A., 1983, Manual de crítica textual, Madril, Editorial Castalia.

CAmino, I., 2011, «Ekialdeko euskararen iraganaz», in Epelde (arg.), 87-153.

Camino, I.; R. Gómez, 1992, «Bonaparteren argitaratzeko irizpideez: Aezkoa, Zaraitzu eta Erronkariko dotrinak (I)», ASJU, 26 (2), 453-581.

DCECH = J. Corominas; J. A. Pascual, 1985, Diccionario crítico etimológico castellano e hispánico (6 liburuki), Madril, Editorial Gredos.

Egurtzegi, A., 2014, «Towards a phonetically grounded diachronic phonology of Basque», UPV/EHU-ko doktorego tesi argitaragabea.

EHHA = Euskaltzaindia, 2008-2016, Euskararen herri hizkeren atlasa, Bilbo, Euskaltzaindia, <www.euskaltziandia.eus/ehha> (kontsulta: 2016-11-16).

Enciso, J., 1990 [1891], Memorias de Julián Gayarre, Bilbo, Editorial Laida.

EPelde, I. (arg.), 2011, Euskal dialektologia: lehena eta oraina, Bilbo, UPV/EHU, «ASJUren gehigarriak», 69.

Estornés LASA, 1984, «Mendigatxa'k Azkue'ri kartak 1902-1916 eta Erronkari'ko uskaratik utzulpen ta goarpenak», FLV, 43, 55-127.

- 1997, Diccionario español-uskara roncalés. Erronkariko uskararen hiztegia, Iruñea, Nafarroako Gobernua.

FAgOAGA, I., 1951, «Una carta en euskera de Julián Gayarre», Gernika, 14, 12-14.

- 1959, Retablo vasco, Zarautz, Auñamendi.

FHV = Mitxelena, 1977 [1964], Fonética histórica vasca, berrarg. in OOCC VI.

FitA, F., 1880, «Suplementos al Diccionario trilingüe del P. Larramendi escritos en 1746 por el P. Fr José de María Carmelita Descalzo", in Modo breve para aprender la lengua vizcayna, Girona, Imp. y Librería de V. Dorca, 41-91. <http://www.kmliburutegia.net/Record/25744> (kontsulta: 2016-03-05).

Gómez, R., 1991, «Erronkarierazko dotrina argitaragabe bat: edizioa eta azterketa», in J. A. Lakarra; I. Ruiz Arzalluz (arg.), Memoriae L. Mitxelena Magistri Sacrum (pars prior), Donostia, Gipuzkoako Foru Aldundia, 375-426.

HH. EE., 1987, Euskal dialektologiaren hastapenak, Bilbo, Udako Euskal Unibertsitatea.

HuALDE, F., [s.d.] «Julian Gayarre: repertorio completo», interneten kontsultagai: <http:// www.juliangayarre.com/images/repertorio.pdf > (kontsulta: 2016-02-28).

LAKARRA, 1996, Refranes y sentencias. Ikerketak eta edizioa, Bilbo, Euskaltzaindia. 
— 1997, «Euskararen historia eta filologia: arazo zahar, bide berri», ASJU, 31 (2), 447-535.

- 2011, "Gogoetak euskal dialektologia diakronikoaz: euskara batu zaharra berreraiki beharraz eta haren banaketaren ikerketaz», in I. Epelde (arg.), 155-241.

LeKAROZ, G., 2014, «Euskararen lekukoak: Erronkari», <http://linguanavarrorum. blogariak.net/2014/04/13/euskararen-lekukoak-erronkari/> (kontsulta: 2016/02/21).

Manterola, J., 2006, ““-a” euskal artikulu definituaren gainean zenbait ohar», in Lakarra; Hualde (arg.), 2006, R. L. Trasken oroitzapenetan ikerketak euskalaritzaz eta hizkuntzalaritza historikoaz (ASJU, 40:1-2), Donostia \& Bilbo, Gipuzkoako Foru Aldundia \& UPV/EHU, 651-676.

Martínez-Areta, M. (arg.), 2013, Basque and Proto-Basque, Frankfurt, Peter Lang, "Mikroglottika», 5.

Mitxelena, K., 1953, "Contribución al conocimiento del dialecto roncalés», berrarg. in OOCC, VII, 571-608.

— 1954, «La posicion fonética del dialecto vasco del Roncal», berrarg. in OOCC VII, 611-647.

- 1964, Sobre el pasado de la lengua vasca, berrarg. in OOCC V: 1-115.

- 1970, Estudio sobre las fuentes del Diccionario de Azkue, berrarg, in OOCC VIII, 29-191.

- 1979, "Vasc. on da / gauza ona da», berrarg. in OOCC VII, 301-314.

OEH = MitXelenA, K., 1987-2005, Orotariko euskal hiztegia (15 tomo), <http://euskaltzaindia.eus/oeh>.

OOCC = MitxelenA, K., 2011, Obras completas (xv liburuki), Lakarra; Ruiz Arzalluz (arg.), Donostia \& Gazteiz, Gipuzkoako Foru Aldundia \& UPV/EHU.

Fr. Migel (ZuZaeta); Fr. Jose (Arakistain), i997, Idazlanak, F. Ondarra; A. Unzueta (arg.), Markina-Xemein, Karmel argitaletxea.

OÑederra, L., 1990, Euskal fonologia: palatalizazioa, Donostia, UPV/EHU.

Padilla-Moyano, M., 2013, «(Des)genitibizazioaren historiaz gehiago: genitibozko subjektu iragangaitzak (ISGEN) ekialdeko euskaran», in R. Gómez et al., (arg.), 2013, Koldo Mitxelena katedraren III. biltzarra, Vitoria-Gasteiz, UPV/EHU, 383-404.

Pagola, R. M.; Iribar I.; Iribar J. J. (arg.), 1997, Bonaparte ondareko eskuizkribuak. Erronkariera, Bilbo, Deustuko Unibertsitatea.

Reguero, U., 2013, «Word order», in M. Martinez Areta (arg.), 2013, 429-460.

Roncaglia, A., 1975, Principi e applicazioni di critica testuale, Roma, Bulzoni.

SAiz Valdivielso, A., 1990, «Prólogo a la presente edición», in J. Enciso 1990 [1891], 79.

Salvoch, O., 2015, Julián Gayarre. La voz del paraíso, Iruñea, Ediciones Eunate.

Ulibarri, K., 2015, «Dotrinazko sermoitegia. Galduriko hizkerak eta dialektologia historikoa», doktorego tesi argitaragabea [zuz.: Blanca Urgell Lázaro].

URGELL, B., 2016, «Lehen euskara modernoa», in Euskararen historia, agertzeko.

YRIZAR, P., 1949 [1981], «Los dialectos y variedades del vascuence», berrarg., in Contribución a la dialectología de la lengua vasca (I), Donostia, Gipuzkoako Aurrezki Kutxa, 95-125.

- 1992, Morfología del verbo auxiliar roncalés, Bilbo \& Iruñea, Euskaltzaindia \& Nafarroako Gobernua.

ZuAzo, K., 1998, Euskalkiak: euskararen dialektoak, Donostia, Elkar. 


\section{Eranskina: J. A. Arakistainen Erronkariko hitzak}

Erronkarierazko lekukotasun «baztertuen» gaineko artikulu honetan, Arakistain karmeldarrak Larramendiri bidaliriko Erronkariko hitzak ekarri nahi ditugu eranskin gisara. Arakistainek 1746an bilduriko material lexikoen lehenengo edizioa Fidel Fitak egin zuen XIX. mendean (Fita, 1880). Ondoren, Fitaren edizioa originalarekin erkatu eta berrikusi zuen Mitxelenak (1970: 172 e. hh.), baina ez zuen edizio berri bat egiteko premia ikusi; horren ordez, oharrak egin zizkion zenbait hitzi, dela Fitaren irakurketa akatsak zuzenduz, dela bestela ulertu behar ziren hitzak aipatuz. Edizio lana egina genuela, zerrenda hauen 1997ko beste edizio baten berri izan dugu, F. Ondarrak eta A. Unzuetak argitaratua, Zuzaeta idazlearen sermoiekin batera (ik. Ondarra; Unzueta, 1997).

Guztiarekin, zerrenda ez da behar beste ezaguna euskalariontzat; beraz, artikulu hau aprobetxatuko dugu lekukotasun hau ere behar lukeen tokian jartzeko, puntu batzuetan lekukotasun garrantzitsua izan baita artikulu honen jardunean. Ez dugu edizio kritiko berri bat egin nahi (nahiz eta zerrenda honen eta Arakistainen eranskin guztien edizio kritiko moderno baten beharra aldarrikatzen dugun): Fitaren eta Ondarra; Unzuetaren edizioen transkribapena agertuko dugu, oro har, lerro hauetan, Mitxelenak egindako zuzenketak aintzat harturik, noski. Honekin batera, jatorrizko eskuizkribuarekin erkatzerik ere izan dugu ${ }^{19}$, eta irakurketa berriren bat proposatzeaz gainera, Fitak gaztelaniazko zatian eginiko eguneraketa grafikoak atzera egin ditugu, jatorrizkoak duena berrezarriz. Tiletetan eta puntuazioan, ordea, egungo ohiturak izan ditugu irizpide. Aurreko edizioen eta hemengoaren artean ezberdintasunak egonik, oharrean emango dugu Fitaren $(\mathrm{F})$ eta Ondarra; Unzuetaren $(\mathrm{O}-\mathrm{U})$ irakurketa, baina oharrik gabe atzerantz egingo ditugu Fitak egindako erdal zatiko eguneratze grafikoak.

Erabilgarritasunaren izenean, karmeldarrak alfabeto hurrenkerari heldu gabe eta gaztelania-euskara ordenan atondu zuena, alderantzizkoan ipini dugu (euskara-gaztelania) eta ordena alfabetikoan antolatu. Sarrera zenbaitetan euskal ordain bi ematen ditu, eta honelakoetan sarrera bitan banatu dugu (erdal zatia bikoiztuz), euskal hitza zerrendan ager dadin. Puntuazioa gaurkotu dugu eta gaztelaniazko testuetan azentuak gaur egungo ohituren arabera eman. Modu honetan, guk uste, ikertzaile zein irakurleentzat zerrenda erabilgarri(ago) bat sortuko dugu, eta xvIII. mendeko Erronkarin bilduriko hitzetara hurbiltzeko beste aukera bat eskaini.

19 Jatorrizko eskuizkribuaren kopia Javier Estebanek lortu zuen Espainiako Historiaren Akademian, eta nire eskuetara Blanca Urgellen bitartez heldu da. Esaldi hau txiro geratzen da biek beharko lituzketen eskerrak jasotzeko. 


\section{Algunos términos del Valle de Roncal}

Aguinguiltza ${ }^{20}$ : Colmillo.

Aizpilcea: Aliquera, assí llaman a una especie de poma ${ }^{21}$.

Aiztercoa, ac: Tixeras pequeñas.

Alaguea $^{22}$ : Pasto del ganado.

Alaguera eroan: Llebar al pasto.

Alagueratu: Llebar al pasto.

Allicoa: Ovillo.

Apal (Gora ta apal): abajo (Arriba y abaxo).

Apana: Pandero.

Aspia ${ }^{23}$ : Muslo.

Besaincoa: Codo.

Borontea: Frente.

Burpilla: Rueca pa ilar lana.

Buztanocha: Ardilla, animal.

Calzaria: Liga para atar la media.

Cetachoa: Zedazo.

Chaucea: Salto.

Chauci: Saltar.

Chaucitu: Saltar.

Chirrina: Rabel.

Chorizalea: Rapapájaro, especie de gavilán.

Chorta: Trago.

Chucha: Saliva.

Clima $^{24}$ : Saco.

Cochesa: Aspa para aspar.

Concarea ${ }^{25}$ : Robo (de medir).

20 Arakistainek birritan idatzi du, lehenengoa ondo irakurtzen ez delako, nonbait.

21 pomas (F, O-U).

22 alaguez (F); Mitxelenaren zuzenketa.

23 Arakistainek birritan idatzi du, lehenengoa ondo irakurtzen ez delako, nonbait.

24 «La forma moderna, que he oído bastantes veces, es krima, pero pudo existir klima, más fiel a la etimologia (quilma)». Mitxelenaren oharra.

25 Concarca (F, O-U); Arakistainen lekukotasunetik bakarrik ageri da konkarka OEHan (s. $v$. konkarka), eta gure irakurketa berriak hiztegi hartan bertan den gongari (OEH, s. v. gongari) hitzarekin bat egingo luke.
Cunchurria: Garganta.

Curzuria: Devanadera.

Eburnia: Infierno.

Elchanoa: Puchero.

Erden: Hallar.

Erguia: Novillo.

Erraiac: Livianos.

Gaitzurua: Quartal.

Gora ta apal: Arriba y abaxo.

Guerguiscoac: Calzones.

Hanaia: Centeno ${ }^{26}$.

Heria: Dedo pólice.

Hilincha: Milano.

Iansoa: Tocino.

Iceia: Abeto, árbol.

Lantrua: Montera.

Latsuna: Cal.

Lerra: Pino, y particularmente el que arde.

Lotu (naiz, cera, da): Dormir.

Marfuca: Catarro.

Margua: Fressa.

Mugurdia. Churdon (pienso es árbol).

Musquentra: Lagartija.

Narra: Espino.

Nasaia: Camisa de muger.

Nescaneguna: Sábado.

Nieztura: Centella.

Olabea: Cribo ralo para quitar la paja.

Ollojalea ${ }^{27}$ : Gavilán.

Ondarbea: Cribo.

Ondarra: Orillo ${ }^{28}$ en lo baxo del vestido.

Ozcamina: Dentera.

Piscoltea: Ombligo.

Saltacha: Tiemblo, assi llaman a un árbol.

\footnotetext{
26 Centono (O-U).

27 Ollajalea $(\mathrm{F})$.

28 Ovillo (F).
} 
Siyn (naiz, cera, da): Venir.

Taica: Tocado de la cabeza.

Üistia ${ }^{29}$ : Ciflo o flauta.

Umbula: Rueda de molino ${ }^{30}$.

Utchea: Ciego.

Xin (naiz, cera, da): Venir.

Zaipecoa: Basquiña ${ }^{31}$.

Zumaquia: Sauce o mimbre grande de los ríos.

29 Uistia (F); Arakistainek birritan idatzi du, lehenengoa ondo irakurtzen ez delako, nonbait; eta bigarrenean dieresia jartzen du ü gainean.

30 molinos $(\mathrm{F})$.

31 jat. Basquina, Fitak zuzendua.

$430 \quad$ Fontes Linguae Vasconum (FLV), 122, julio-diciembre, 2016, 409-432 ISSN: 0046-435X ISSN-e: 2530-5832 


\section{LABURPENA}

\section{Julian Gaiarreren euskal gutuna: edizioa eta azterketa}

Artikulu honetan Julian Gaiarre (1844-1890) tenor nafarrak bere izebari euskaraz idatziriko gutun famatua editatuko dugu. Gutun hau normalean erronkariarra euskalduna zela frogatzeko besterik ez da aipatu, baina lan honek ikuspegi mugatu honetatik atera eta oraindik egiteke zegoen testuaren alderdi linguistikoa lantzea du helburu, xIx. mendeko Erronkariko euskarari buruz hitz egiten digun lekukotasun garrantzitsua baita. Egindako transkribapenak konparatu, irakurketa berriak proposatu eta eskutitzaren hizkuntz ezaugarri garrantzitsuenak komentatuko ditugu, erronkarieraren gainontzeko lekukotasunen testuinguruan jarriz. Era berean, gutxitan aipaturiko erronkarierazko lekukotasunekin jarraituz, artikulu honen eranskin moduan, XVIII. mende erdialdean J. A. Arakistain fraideak Erronkari hiribilduan jaso zuen hitz zerrenda ekarriko dugu.

Gako hitzak: testu edizioa; erronkariera; dialektologia; gutuna; Gaiarre.

\section{RESUMEN}

\section{La carta de Julian Gayarre: edición y estudio}

Es este artículo editamos la famosa carta que el tenor navarro Julián Gayarre (18441890) escribió a su tía en euskera. La carta es mencionada normalmente para mostrar que el tenor era vascoparlante, pero en este trabajo queremos estudiarla como testimonio lingüístico, trabajo no hecho hasta la fecha; un testimonio de gran valor al hablarnos del euskera roncalés del s. XIx. Compararemos las principales transcripciones hechas, propondremos una nueva lectura y comentaremos las características lingüísticas más importantes de la misiva, contextualizándola entre los demás testimonios del euskera roncalés. Del mismo modo, siguiendo con testimonios roncaleses poco conocidos, anexo a este artículo traemos una lista de las palabras que recogió el fraile J. A. Arakistain en la villa de Roncal a mediados del s. XviII.

Palabras clave: edición de textos; dialecto roncalés; dialectología; carta; Gayarre.

\section{ABSTRACT}

\section{Julian Gayarre's letter: edition and survey}

In this paper, we present an edition of the famous letter that the tenor Julian Gayarre (1844-1890) wrote to his aunt. This letter has been used to prove that the Roncalese tenor was a speaker of Basque, but in this paper we would like to study the text as linguistic evidence instead, a task that was yet to be carried out. This document is a relevant piece of evidence of the Basque spoken in Roncal in the 19th century. We will 
compare the main transcriptions of the document, suggest a new interpretation of the text and comment on the most important linguistic features of the missive, as well as contextualizing the language in relation to the other witnesses of the Roncalese dialect. Similarly, in order to continue improving our knowledge on little known Roncalese witnesses, we bring a wordlist collected by the friar J. A. Arakistain in the village of Roncal in the middle of the $18^{\text {th }}$ century as an appendix.

Keywords: textual criticism; Roncalese dialect; dialectology; letter; Gayarre. 